\title{
The impact of prospecting strategy on small business performance in Vietnam: the role of broad-scope management accounting system
}

\author{
Quang-Huy Ngo \\ Industrial Management Faculty, Cantho University of Technology, Cantho, Vietnam
}

\begin{abstract}
The purpose of this study is to uncover the role of broad-scope management accounting system (MAS) on the link between prospecting strategy and the performance of small businesses. In particular, this paper hypothesizes that a high degree of prospecting strategy is positively associated with a high degree of broadscope MAS, and a high degree of broad-scope MAS is correlated with a high degree of performance of small businesses. Also, it is hypothesizes that prospecting strategy increases the performance of small businesses. The last hypothesis proposes that broad-scope MAS mediates the link between prospecting strategy and the performance of small businesses. Data was collected from 131 small businesses located in Cantho city to assess the proposed hypothesis. A PLS-SEM was analyzed with the collected data. The results reveal that all hypotheses are supported by the data except the hypothesis describing the relationship between prospecting strategy and the performance of small businesses. It implies that broad-scope MAS fully mediates the link between these two variables.
\end{abstract}

Keywords

broad-scope MAS, performance, prospector, strategy, Vietnam, small business

\section{Introduction}

Since the introduction of "Doi Moi" (Renovation), the Vietnamese economy has transformed dramatically. This policy's central theme is to transform the economy from a central planning economy to a socialist-oriented market economy (Irvin, 1995). Such an approach has a substantial impact on the Vietnamese social-economy. The private sector, particularly small businesses, is one of the fastest-growing sections in the Vietnamese economy because of some benefits gained from this policy (see Freeman, 1996; Hansen et al., 2009).

Although the fast-growing small business sector plays a more crucial role in the economy, their management practices are not well understood. In the strategic literature on small business, it is proposed that strategy has an impact on performance (Blackburn et al., 2013). Although most of Vietnamese research focuses on large businesses, a lack of attention has been paid to small businesses. As such, this limits our knowledge of how strategic choice influences the performance of small businesses. Besides, Chong and Chong (1997) found that the positive impact of strategy on performance is indirect through a management accounting system (MAS) when they examined the role of MAS in strategic business units. Gul et al. (1993) found that MAS allows business owners to improve performance. In summary, it is expected that MAS may impact the relationship between strategy and performance.

Thus, this study's purpose is to address the role of MAS on the relationship between strategy and performance of small businesses in Vietnam. More specifically, this study proposes that businesses following this prospecting strategy are 
more likely to demand more broad-scope MAS and, as such, achieve a high degree of performance. Besides, this study proposes that the positive effects of strategy on performance are indirect through broad-scope MAS. Specifically, this indirect effect is mediated by broad-scope MAS on the link between prospecting strategy and performance.

The structure of this paper is outlined as follows. The next section is the provision of the literature review and developments of the hypothesis. After that, the methodology is introduced. In the next section, results and discussion are described. The last section concludes and indicates limitations as well as suggestions for future studies.

\section{Literature review and hypothesis development}

\subsection{Literature review}

\subsubsection{Strategic types}

Miles and Snow (1978) argue that there are four types of strategies, including prospectors, defenders, analyzers, and reactors. Four strategic types are usually examined along the continuum of defender and prospector because it is assumed that the analyzers are the results of a hybrid strategy, which is the combination of analyzers and defenders. The reactors are believed to have no strategy due to their reactions based on market environments (Kald et al., 2000). On the one hand, prospectors provide products or services to meet customers' demands by enhancing customers' experiences of the products and services' features, functionality, uniqueness, and responsiveness. Thus, the biggest concern of the organization following such a strategy is to collect data regarding customers' demands and market trends (Govindarajan, 1986). In contrast, defenders focus on the provision of products and services with high quality and low cost. In this way, this strategy allows organizations to maintain their market shares through the improvement of operational efficiency. Thus, this strategy requires more information for efficiency improvement, such as costs (Govindarajan, 1986).

\subsubsection{MAS and its effectiveness}

MAS is commonly referred to as the system providing information for decision-making. In academic terminology, this system refers to the systematic use of management accounting practices, which are designed to enhance the effectiveness of the decision-making process. Thus, this use allows the achievement of organizational goals (Chenhall, 2003). Studies on MAS focus only on financial and internal-oriented data (Rasid et al., 2014). However, the modern theme in management accounting indicates this system provides not only financial data but also non-financial data as well as data related to external environments (Soobaroyen \& Poorundersing, 2008).

One of MAS's crucial characteristics is broadscope MAS, which has received much attention from researchers in the management accounting fields. Broad-scope MAS provides information covering external, non-financial, and futureoriented data (Chenhall, 2003; Soobaroyen \& Poorundersing, 2008). In contrast, narrow-scope MAS provides information relating only to financial, historical, and internal-oriented data (Tillema, 2005). It is suggested that modern MAS is associated with broad-scope characteristics, while traditional MAS is correlated with narrowscope characteristics (Chong \& Eggleton, 2003).

The dominant research theme on MAS is to examine how MAS enhances performance (Henri, 2004; Hoque, 2004). Previous studies reveal that broad-scope MAS has a positive association with performance (Chong \& Chong, 1997; Ghasemi et al., 2016; Ghasemi et al., 2019; Hammad et al., 2013; Soobaroyen \& Poorundersing, 2008). On the same lines with previous studies, this paper expects the same effects, which broad-scope MAS induces small business performance.

\subsubsection{Contingency theory in management accounting}

Emmanuel et al. (1990) argue that one crucial notion of contingency-based research is to examine the fit between contextual factors and MAS because this fit allows a high degree of effectiveness. Contingency-based theorists suggest that strategy is an essential contextual, which should be considered when examining how MAS fosters performance (Chenhall, 2003; Gerdin \& Greve, 2004; Hayes, 1977; Otley, 2016; Waterhouse \& Tiessen, 1978). In line with this suggestion, this study proposed the following hypotheses. 


\subsection{Hypothesis developments}

\subsubsection{The link between prospecting strategy and broad-scope MAS}

Managers in prospecting organizations are more likely to require more information regarding external environments. Organizations following this strategy to attempt to become pioneers in the market through research and development (Hambrick, 1982). Prospectors continually focus on developing new techniques and shaping their products/services domain in line with customers' demands (Govindarajan, 1988; Miles \& Snow, 1978). As a result, it is suggested that information focusing on external environments is critical for them to deliver their products/services to customers (Ewusi-Mensah, 1981). Thus, information as non-financial and future-orientated data is useful to these prospectors (Abernethy \& Guthrie, 1994; Chong \& Chong, 1997).

Management accounting literature provides more insight into why prospectors require broadscope MAS. When an organization follows a prospecting strategy, managers are more likely to work under high uncertainty (Andrews, 2008; Hoque, 2004). Management accounting theorists strongly suggest that when uncertainty is high, managers find a sophisticated design of MAS to be useful, because it allows them to reduce the degree of uncertainty, and, as such, improves their performance (Agbejule, 2005; Gul, 1991; Gul \& Chia, 1994; Hammad et al., 2013). Chong and Chong (1997) found that when a strategic business unit follows a prospecting strategy, the managers use more broad-scope MAS. Thus, in the same vein, this paper expects the prospecting strategy managers working at Vietnamese public hospitals to use more broad-scope MAS. The first hypothesis is proposed as follows.

H1: A high degree of prospecting strategy is positively associated with a high degree of broadscope MAS.

\subsubsection{The link between broad-scope MAS and small business performance}

MAS allows organizations to improve their performance by information provision. In a specific way, it is argued that organizations need to scan and monitor the external environments regarding the thread of potentials as well as current competitions, powers of suppliers, and demands of customers to gain competitive advantage, and as such allows the organizations to survive in a competitive market (Porter, 1985). As broad-scope MAS provides information relating to dimension focus, future orientation, and nonfinancial data (Chenhall \& Morris, 1986), this type of information may allow these businesses to improve performance. For example, organizations can gain competitive advantages by using the information to scan and monitor competitors' actions, gain insights into customers' needs, and reduce suppliers' bargaining power (Johnston \& Vitale, 1988; Porter \& Millar, 1985). As a consequence, the enhancement of competitive advantages leads to an increase in market shares. Because it is argued that the enhancement of market share is the key indicator of long-term profitability (Pogue, 1990), it is expected that broad-scope MAS induces organizational performance.

In the same vein, this paper expects the same effects on small businesses. Mainly, broad-scope MAS allows for the improvement of organizational performance as small business performance. It is suggested that management accounting information enhances performance through feedback improvements (see Otley, 1999; Sprinkle, 2000). Feedback is proposed in assisting owners in improving performance in the extent to which it allows the high use of relevant information to identify and correct errors as well as reduction of task uncertainty (see Vroom, 1964). Similarly, it is argued that the use of broadscope MAS induces high identifications and corrections of errors and reduction of task uncertainty, and in turn, leads to improvement of performance (see Mia \& Clarke, 1999). Hence, the second hypothesis is proposed as followed.

H2: A high degree of broad-scope MAS is positively associated with a high degree of small business performance.

\subsubsection{The link between strategy and small business performance}

The choice of a prospecting strategy may allow high organizational performance. Characteristics found in prospecting strategy drive small businesses to continuously reshape the market, adapt, and apply new technology and management practices to gain competitive advantages. As a result, Miles and Snow (1978) propose that prospecting strategy allows high performance. Moore (2005) and Naranjo-Gil (2004) found a significant positive relationship between these two variables. Similarly, this paper expects a similar effect, in which prospecting strategy increases 
small business performance. Thus, the third hypothesis is proposed as followed.

H3: A high degree of prospecting strategy is positively associated with a high degree of small business' performance.

\subsubsection{Broad-scope MAS is the mediator between prospecting strategy and small business performance}

Contingency-based theorists suggest that broadscope MAS is a mediator between contextual factors and performance. Notably, a MAS should be designed according to the organizations' contexts to enhance performance (Bruns \& Waterhouse, 1975). Instead, its design should be design to be "fit" with contextual factors as a strategy (Gordon \& Miller, 1976; Otley, 1980; Waterhouse \& Tiessen, 1978). The term "fit" is the most concerned in the contingency-based studies. It is suggested that the form of fits can be investigated by considering MAS as a mediator (Gerdin \& Greve, 2004). More specifically, they argue that when contextual variables correlate with one of MAS, and it correlates with the dependent variable as performance, cartesiancontingency mediation represents the form of fits. Following this suggestion, this paper proposes the fourth hypothesis as followed.

H4: Broad-scope MAS is the mediator between prospecting strategy and small business performance.

\section{Method}

\subsection{Data collection}

A convenience sampling technique was used to collect data. Data was collected by sending a survey to target respondents having their own business in Cantho city. This study takes into account four criteria for selections. First, these small businesses operate in manufacturing areas because the high demands of information for decision-making drives these businesses to adopt MAS. Second, this business's labor is between 10 and 100 employees, which is sufficient for small businesses. Third, these businesses have operated for more than three years to guarantee that MAS is available in these businesses. Fourth, the respondents are the owners of the business to ensure that they can use MAS for decisionmaking to find performance improvement.

The process of sending consists of two phrases. First of all, the list of email addresses of business was obtained from the small business associations of Cantho city. This list contains 1,000 email addresses. Second, an email, which consists of an invitation letter and the link to access the online survey, was sent to the target emails. After four weeks, 143 respondents agreed to participate in the research by filling the survey. Among these, 131 observation was used to analyze, and the rest was removed, because the majority of empty values exists in the survey, and the respondents, who filled the survey, are not the owners. In total, the respondents' rate of this study is $13.1 \%$.

\subsection{Measures}

\subsubsection{Prospecting strategy (PROS)}

The prospecting strategy is measured by adopting an instrument from Moore (2005). This instrument consists of 6 items. Some modifications were made before sending out to the respondents due to the original instruments used in the retailing context. This instrument asks respondents to indicate their agreement regarding the statements which best describe their business' behavior. A 5-point Likert scale, ranging from (1) highly disagree to (5) highly agree, was used to measure the degree to which respondents agree with the statements.

\subsubsection{Broad-scope MAS (MAS)}

An instrument from the study of Chenhall and Morris (1986) was measured in this variable. This instrument consists of 5 items. This instrument was used in several contexts, including hospitals (Hammad et al., 2013), financial institutes (Ghasemi et al., 2016), and manufacturing companies (Soobaroyen \& Poorundersing, 2008), and as a result, it poses high reliability. A 5-point Likert scale, ranging from (1) highly disagree to (5) highly agree, was used to measure the degree to which respondents use the information for decision-making.

\subsubsection{Small business performance (PER)}

Commonly, some financial indicators such as ROA and ROS are used to measure small business performance. However, such use creates a bias in measuring small business performance due to short reflections of actual performance. It is shown that the owners of this business consider non-financial indicators as well as financial indicators as a part of small business performance because the owners emphasize not only profitability but also other targets relating to 
business goals (Jarvis et al., 2000). As a result, measuring this kind of performance should be appropriate by asking the owners to rate their performance base on their target attainments.

An instrument was adopted from Cadez and Guilding (2008) with minor modifications made to measure small business performance. In this instrument, respondents are asked to indicate their agreement in the extent to which their business attaint some targets related to return on investment, the margin on sales, capacity utilization, customer satisfaction, product/service quality, the introduction of new products/services, and market share. A 5-point Likert scale, ranging from (1) - well below average - to (5) - well above average, was used to measure this instrument.

\section{Results}

\subsection{Hypothesis testing}

This study uses SmartPLS version 3.2.7, a PLSSEM tool, to test the proposed model. The psychometric properties of the measurement model were examined first, and the structural model's estimation was assessed later.

\subsubsection{Measurement models}

Examining the measurement model consists of two steps. In the first step, the unidimensionality of all of the constructs was assessed by the conduction of principal axis factoring with Oblimin rotation (see Fabrigar et al., 1999). The result reveals that the number of intended items having loading higher than 0.5 correspond to three factors, which its eigenvalue is more than 1 .

The second step is to examine the convergent validity, discriminant validity, and internal consistency of items as well as the multicollinearity among these items. Table 1 suggests a sufficient degree of convergent validity due to three conditions (Fornell \& Larcker, 1981). First, the average variance extracted (AVE) value higher than 0.5. Second, each item's outer loadings on its respective construct are higher than other cross-loadings on other constructs. Third, items' outer-loading on its respective constructs is higher than 0.5 (Fornell \& Larcker, 1981) (Fornell \& Larcker, 1981) (Fornell \& Larcker, 1981) (Fornell \& Larcker, 1981) (Fornell \& Larcker, 1981) (Fornell \& Larcker, 1981). Besides, internal consistency is well established because The CR scores and Cronbach's Alpha are necessarily higher than the 0.70 threshold value (Hair et al., 2011). Also, the VIFs of each item is less than the threshold value of 5 , which indicates an absence of multicollinearity (Hair et al., 2011).

Table 1 Validity of measurement models

\begin{tabular}{r|r|r|r|r|r|r|r}
\hline & Cronbach's Alpha & CR & AVE & & 1 & 2 & 3 \\
\hline MAS & 0.808 & 0.874 & 0.635 & 0.797 & 0.797 & \\
\hline PERF & 0.841 & 0.879 & 0.519 & 0.720 & 0.314 & 0.720 & 0.245 \\
\hline PROS & 0.840 & 0.882 & 0.557 & 0.762 & 0.412 & 0.762 \\
\hline
\end{tabular}

\subsubsection{Structural model}

Hair et al. (2011) suggested that assessing the statistical significance of the parameter estimates examines through a bootstrapping procedure with 5,000 replacements. It is also required that the assessment of multicollinearity between latent variables, the predictive validity of the parameter estimates as well as predictive power before assessing the significance of the hypothesized paths must be made. The results reveal the absence of multicollinearity between the latent variable due to the VIF of each latent less threshold value of 5 (Hair et al., 2011). The parameter estimates' predictive validity is valid because the Stone-Geisser $\mathrm{Q}^{2}$ value (Geisser, 1974; Stone, 1974) is larger than zero (Chin,
1998; Hair et al., 2011). Besides, the predictive power of the path is also assessed by examining the $\mathrm{R}^{2}$ value. Thus, it is safe to examine the significance of the hypothesized paths.

The results indicate there is a positive association between prospecting strategy and broad-scope MAS $(\beta=0.412, p<0.001)$. Thus, it supports the hypothesis H1. Besides, the results show that broad-scope MAS is significantly and positively associated with small business performance $(\beta=0.257, p=0.011)$, and therefore hypothesis $\mathrm{H} 2$ is supported. Finally, the relationship between prospecting strategy and performance is insignificant $(\beta=0.139, p=0.207)$, and as such, it rejects hypothesis $\mathrm{H} 3$.

The hypothesis $\mathrm{H} 4$ requires the assessment of mediation. This study follows the suggestions 
described by Zhao et al. (2010) to assess the mediating hypothesis. A bootstrapping procedure with 5,000 replacement was used to assess the mediating hypothesis (Hair et al., 2017). The estimation of indirect effects requires the assessment of their significances and examination of their confidence intervals (Preacher \& Hayes, 2008).

Table $2 \mathrm{R} 2$, R2 adjusted, and $\mathrm{Q}^{2}$

\begin{tabular}{r|r|r|r}
\hline & $R^{2}$ & $R^{2}$ adjusted & $Q^{2}$ \\
\hline MAS & 0.170 & 0.163 & 0.096 \\
\hline PERF & 0.115 & 0.101 & 0.046 \\
\hline PROS & & & \\
\hline \multicolumn{4}{|c}{ Source: Outputs from the SmartPLS analysis }
\end{tabular}

\section{Discussion}

This paper is consistent with previous studies fourfold. First, regarding the path between prospecting strategy and broad-scope MAS, the results reveal a significant positive relationship between these two variables. It is in line with Chong and Chong (1997). They found that strategic business units following prospecting strategy require broad-scope MAS to improve managerial decision-making effectiveness. Similarly, Naranjo-Gil (2004) found that public hospital in Spain, which have an orientation to prospecting strategy, design their MAS sophisticatedly in the extent to which this system provides broad-scope MAS information.

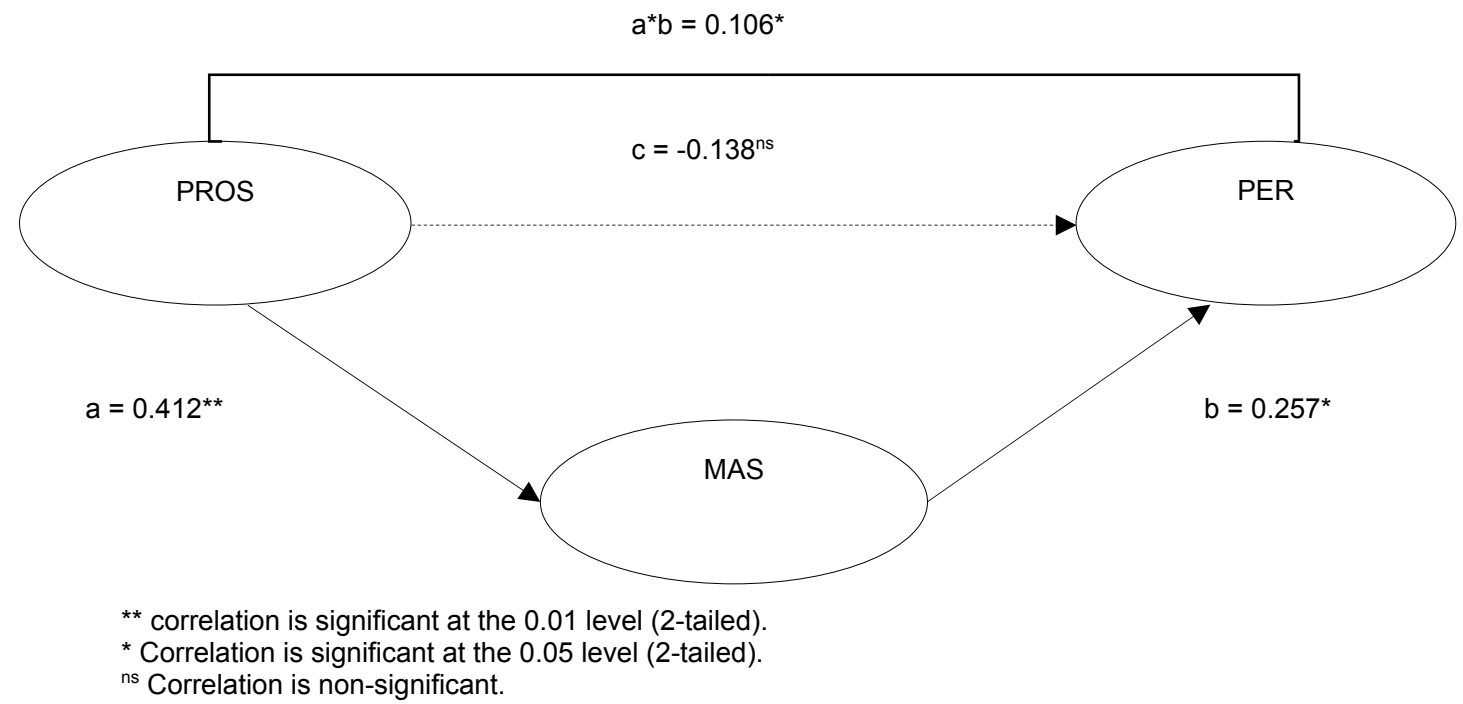

Figure 1 Results of structural model Source: Author's source

The results reveal a significant correlation between prospecting strategy and broad-scope MAS $(\mathrm{a}=0.412, p<0.001)$ as well as broad-scope MAS and performance $(b=0.257, p=0.011)$. Besides, the results show that the indirect effect (PROS -> MAS $->$ PER) is significant $\left(\mathrm{a}^{*} \mathrm{~b}=0.106, p=0.025\right)$, and its confidence interval is from a lower bound of 0.023 to an upper bound of 0.210 , indicating the exclusion of zero. Hence, this confirms that broad-scope MAS is the mediator between prospecting strategy and the performance of small businesses. Moreover, the results also reveal that the insignificant direct effects between prospector strategy and performance $(\mathrm{c}=-0.138, p=0.232)$ when two other paths are in the model. Hence, it supports the full mediating effects of MAS.
Second, with respect to the path between broad-scope MAS and performance, the results are in line with previous studies. At an individual level, Ghasemi et al. (2016), Ghasemi et al. (2019), and Hammad et al. (2013) established that broad-scope MAS allows managers to improve their performance effectively. Chong and Chong (1997) found a positive relationship between broad-scope MAS and strategic business performance at the business unit level. In the same vein, this study shows that broad-scope MAS positively correlated with small business performance.

Third, relating to the insignificant path between prospecting strategy and small business performance, this study is in line with Chong and Chong (1997). More specifically, they found an insignificant relationship between prospecting 
strategy and strategic business units' performance when controlling for the path between prospecting strategy and broad-scope MAS and the path between broad-scope MAS and the performance of these units. They argued that the effects of prospecting strategy on performance are indirect rather than direct because broad-scope MAS fosters intervening (or mediating) effects on the relationship between strategic choices of prospector and the performance of strategic business units. Thus, the results of this study support this argument.

Fourth, the results are also in line with previous studies, which examines whether or not MAS is the mediator between contextual factors and performance. Ghasemi et al. (2016) found the mediating effects of broad-scope MAS on the relationship between market competition and managerial performance. Similarly, Ghasemi et al. (2019) found that broad-scope MAS mediates the link between technology and managerial performance. In the same way, this study shows a mediating impact of broad-scope MAS on the link between prospecting strategy and small business performance.

\section{Conclusion}

This study aims to uncover the role of broadscope MAS on the link between prospecting strategy and performance of small businesses in Vietnam. This paper proposes that prospecting strategy is positively associated with broad-scope MAS and the performance of small businesses in Vietnam. Also, it is proposed that high broadscope MAS is positively correlated with a high performance of small businesses. Besides, this paper proposes that broad-scope MAS is the mediators between prospecting strategy and performance. The results provide empirical evidence supporting these hypotheses except the link between prospecting strategy and performance. Hence, this paper is in line with Chong and Chong (1997), who revealed that only the fit between strategy and MAS fosters organizational performance.

Similar to any research, the results of this study should be interpreted with some little concerns. First, it is necessary to generalize the results with care due to only small businesses located in Cantho city. Second, this paper also subjects to the limitations of small sample sizes and low response rates.

Despite some limitations, this study provides a enrich avenue for future studies. First, future studies should replicate this study by collecting the data in other areas of Vietnam. Second, future studies should take into account other characteristics of MAS, such as timely, integration, and aggregation, because this study only examines broad-scope MAS. By doing so, the future study can investigate the fit between strategy and these characteristics and gain insight into how and why this fit induces performance. Third, it is suggested that the development of regions may impact small businesses (see Chivu, 2019). Therefore, the differentiation in the development influences the strategic choice. Future studies may replicate this study in the underdeveloped area of Vietnam to examine the validity of this model. Fourth, it is revealed that dynamic capability is crucial to organizations (Kareem \& Alameer, 2019). Thus, future studies should include this variable in this model to gain more insight into the role of capabilities on strategic choices' effectiveness. Last but not least, it is also shown that open innovation is critical to small and medium businesses (Janković \& Golubović, 2019). Therefore, future studies can extend this model by examining whether or not the fit between open innovation and prospecting strategy leads to higher performance of small businesses because prospecting strategy emphasizes innovation to find performance implication.

\section{References}

Abernethy, M. A., \& Guthrie, C. H. (1994). An empirical assessment of the "fit" between strategy and management information system design. Accounting \& Finance, 34(2), 49-66. https://doi.org/10.1111/j.1467-629X.1994.tb00269.x

Agbejule, A. (2005). The relationship between management accounting systems and perceived environmental uncertainty on managerial performance: a research note. Accounting and Business Research, 35(4), 295305.

https://doi.org/10.1080/00014788.2005.9729996

Andrews, R. (2008). Perceived environmental uncertainty in public organizations: An empirical exploration. Public Performance \& Management Review, 32(1), 25-50. http://dx.doi.org/10.2753/PMR1530-9576320102

Blackburn, R. A., Hart, M., \& Wainwright, T. (2013). Small business performance: business, strategy and owner-manager characteristics. Journal of small business and enterprise development, 20(1), https://doi.org/10.1108/14626001311298394

Bruns, W. J., \& Waterhouse, J. H. (1975). Budgetary control and organization structure. Journal of Accounting Research, 13(2), 177-203. https://doi.org/10.2307/2490360 
Cadez, S., \& Guilding, C. (2008). An exploratory investigation of an integrated contingency model of strategic management accounting. Accounting, organizations and society, 33(7-8), 836-863. doi:https://doi.org/10.1016/j.aos.2008.01.003

Chenhall, R. H. (2003). Management control systems design within its organizational context: findings from contingency-based research and directions for the future. Accounting, organizations and society, 28(2-3), 127-168. https://doi.org/10.1016/S0361-3682(01)00027-7

Chenhall, R. H., \& Morris, D. (1986). The impact of structure, environment, and interdependence on the perceived usefulness of management accounting systems. Accounting Review, 61(1), 16-35.

Chin, W. W. (1998). The partial least squares approach to structural equation modeling. Modern methods for business research, 295(2), 295-336.

Chivu, L. (2019). Local entrepreneurship and social services in Romania. Territorial analysis. European Research on Management and Business Economics, 25(2), 79-86. https://doi.org/10.1016/j.iedeen.2019.04.001

Chong, V. K., \& Chong, K. M. (1997). Strategic choices, environmental uncertainty and SBU performance: a note on the intervening role of management accounting systems. Accounting and Business Research, 27(4), 268-276. https://doi.org/10.1080/00014788.1997.9729553

Chong, V. K., \& Eggleton, I. R. (2003). The decisionfacilitating role of management accounting systems on managerial performance: the influence of locus of control and task uncertainty. Advances in Accounting, 20, 165-197. https://doi.org/10.1016/S0882-6110(03)20008-0

Emmanuel C., Otley D., Merchant K. (1990) Accounting for Management Control. Springer. https://doi.org/10.1007/978-1-4899-6952-1 13

Ewusi-Mensah, K. (1981). The external organizational environment and its impact on management information systems. Accounting, organizations and society, 6(4), 301-316. https://doi.org/10.1016/0361-3682(81)90010-6

Fabrigar, L. R., Wegener, D. T., MacCallum, R. C., \& Strahan, E. J. (1999). Evaluating the use of exploratory factor analysis in psychological research. Psychological methods, 4(3), 272. https://doi.org/10.1037/1082-989X.4.3.272

Fornell, C., \& Larcker, D. F. (1981). Evaluating structural equation models with unobservable variables and measurement error. Journal of marketing research, 18(1), 39-50.

https://doi.org/10.2307/3151312

Freeman, D. B. (1996). Doi Moi policy and the smallenterprise boom in Ho Chi Minh City, Vietnam. Geographical review, 86(2), 178-197. https://doi.org/10.2307/215955

Geisser, S. (1974). A predictive approach to the random effect model. Biometrika, 61(1), 101-107. https://doi.org/10.1093/biomet/61.1.101

Gerdin, J., \& Greve, J. (2004). Forms of contingency fit in management accounting research-a critical review. Accounting, organizations and society, 29(3-4), 303326.

https://doi.org/10.1016/S0361-3682(02)00096-X
Ghasemi, R., Azmi Mohamad, N., Karami, M., Hafiz Bajuri, N., \& Asgharizade, E. (2016). The mediating effect of management accounting system on the relationship between competition and managerial performance. International Journal of Accounting and Information Management, 24(3), 272-295. https://doi.org/10.1108/IJAIM-05-2015-0030

Ghasemi, R., Habibi, H. R., Ghasemlo, M., \& Karami, M. (2019). The effectiveness of management accounting systems: evidence from financial organizations in Iran. Journal of Accounting in Emerging Economies, 9(2), 182-207.

https://doi.org/10.1108/JAEE-02-2017-0013

Gordon L. A., Miller D. (1976) A contingency framework for the design of accounting information systems. In Emmanuel C., Otley D., Merchant K. (eds) Readings in Accounting for Management Control (pp. 569-585). Springer, Boston, MA. https://doi.org/10.1007/978-1-4899-7138-8 26

Govindarajan, V. (1986). Impact of participation in the budgetary process on managerial attitudes and performance: Universalistic and contingency perspectives. Decision Sciences, 17(4), 496-516. https://doi.org/10.1111/j.1540-5915.1986.tb00240.x

Govindarajan, V. (1988). A contingency approach to strategy implementation at the business-unit level: integrating administrative mechanisms with strategy. Academy of management journal, 31(4), 828-853. https://doi.org/10.2307/256341

Gul, F. A. (1991). The effects of management accounting systems and environmental uncertainty on small business managers' performance. Accounting and Business Research, 22(85), 57-61. https://doi.org/10.1080/00014788.1991.9729418

Gul, F. A., \& Chia, Y. M. (1994). The effects of management accounting systems, perceived environmental uncertainty and decentralization on managerial performance: a test of three-way interaction. Accounting, organizations and society, 19(4-5), 413426. https://doi.org/10.1016/0361-3682(94)90005-1

Gul, F. A., Glen, W., \& Huang, A. R. (1993). The Effects of Environmental Uncertainty, Computer Usage, and Management Accounting Systems on Small Business. Journal of Small Business Finance, 2(3), 251-271. http://hdl.handle.net/10419/114660

Hair, J. F., Hult, G. T. M., Ringle, C. M., Sarstedt, M., \& Thiele, K. O. (2017). Mirror, mirror on the wall: a comparative evaluation of composite-based structural equation modeling methods. Journal of the Academy of Marketing Science, 45(5), 616-632. https://doi.org/10.1007/s11747-017-0517-x

Hair, J. F., Ringle, C. M., \& Sarstedt, M. (2011). PLS-SEM: Indeed a silver bullet. Journal of Marketing theory and Practice, 19(2), 139-152. https://doi.org/10.2753/MTP1069-6679190202

Hambrick, D. C. (1982). Environmental scanning and organizational strategy. Strategic management journal, 3(2), 159-174. https://doi.org/10.1002/smj.4250030207

Hammad, A. S., Jusoh, R., \& Ghozali, I. (2013). Decentralization, perceived environmental uncertainty, managerial performance and management accounting system information in Egyptian hospitals. International Journal of Accounting and Information Management, 21(4), 314-330. https://doi.org/10.1108/IJAIM-02-2012-0005 
Hansen, H., Rand, J., \& Tarp, F. (2009). Enterprise growth and survival in Vietnam: Does government support matter? The Journal of Development Studies, 45(7), 1048-1069. https://doi.org/10.1080/00220380902811025

Hayes, D. C. (1977). The contingency theory of managerial accounting. Accounting Review, 22-39." should be changed to "Hayes, D. (1977). The Contingency Theory of Managerial Accounting. The Accounting Review, 52(1), 2239. Retrieved June 10, 2021, from: http://www.jstor.org/stable/246029

Henri, J.-F. (2004). Performance measurement and organizational effectiveness: Bridging the gap. Managerial Finance, 30(6), 93-123. https://doi.org/10.1108/03074350410769137

Hoque, Z. (2004). A contingency model of the association between strategy, environmental uncertainty and performance measurement: impact on organizational performance. International business review, 13(4), 485502.

https://doi.org/10.1016/j.ibusrev.2004.04.003

Irvin, G. (1995). Vietnam: assessing the achievements of Doi Moi. The Journal of Development Studies, 31(5), 725-750. https://doi.org/10.1080/00220389508422387

Janković, G., \& Golubović, M. (2019). Open innovation in small and medium-sized enterprises. Ekonomika, 65(3), 89-101. https://doi.org/10.5937/ekonomika1903089J

Jarvis, R., Curran, J., Kitching, J., \& Lightfoot, G. (2000). The use of quantitative and qualitative criteria in the measurement of performance in small firms. Journal of small business and enterprise development, 7(2), 123134. https://doi.org/10.1108/EUM0000000006834

Johnston, H. R., \& Vitale, M. R. (1988). Creating competitive advantage with interorganizational information systems. MIS quarterly, 12(2), 153-165. https://doi.org/10.2307/248839

Kald, M., Nilsson, F., \& Rapp, B. (2000). On strategy and management control: the importance of classifying the strategy of the business. British Journal of Management, 11(3), 197-212. https://doi.org/10.1111/1467-8551.00161

Kareem, M. A., \& Alameer, A. A. A. (2019). The Impact of Dynamic Capabilities on Organizational Effectiveness. Management \& Marketing. Challenges for the Knowledge Society, 14(4), 402-418. https://doi.org/10.2478/mmcks-2019-0028

Mia, L., \& Clarke, B. (1999). Market competition, management accounting systems and business unit performance. Management Accounting Research, 10(2), 137-158. https://doi.org/10.1006/mare.1998.0097

Miles, R. and C. Snow. (1978). Organizational Strategy, Structure and Process. London: McGraw Hill

Moore, M. (2005). Towards a confirmatory model of retail strategy types: an empirical test of Miles and Snow. Journal of Business Research, 58(5), 696-704. https://doi.org/10.1016/j.jbusres.2003.09.004

Naranjo-Gil, D. (2004). The role of sophisticated accounting system in strategy management. International Journal of Digital Accounting Research, 4(8), 125-144. https://doi.org/10.4192/1577-8517-v4 5
Otley, D. (1980). The contingency theory of management accounting: achievement and prognosis. Accounting, organizations and society, 5(4), 413-428. https://doi.org/10.1016/0361-3682(80)90040-9

Otley, D. (1999). Performance management: a framework for management control systems research. Management Accounting Research, 10(4), 363-382. https://doi.org/10.1006/mare.1999.0115

Otley, D. (2016). The contingency theory of management accounting and control: 1980-2014. Management Accounting Research, 31, 45-62. https://doi.org/10.1016/j.mar.2016.02.001

Pogue, G. (1990). Strategic management accounting and marketing strategy. Management Accounting, 68(1), 4648. https://doi.org/10.1108/18325911011048772

Porter, M. E. (1985) Competitive Advantage. Creating and Sustaining Superior Performance. New York: Free Press.

Porter, M. E., \& Millar, V. E. (1985). How information gives you competitive advantage. Harvard Business Review, 63(4), 149-160.

Preacher, K. J., \& Hayes, A. F. (2008). Asymptotic and resampling strategies for assessing and comparing indirect effects in multiple mediator models. Behavior research methods, 40(3), 879-891. https://doi.org/10.3758/BRM.40.3.879

Rasid, S. Z. A., Isa, C. R., \& Ismail, W. K. W. (2014). Management accounting systems, enterprise risk management and organizational performance in financial institutions. Asian Review of Accounting, 22(2), 128-144.

https://doi.org/10.1108/ARA-03-2013-0022

Soobaroyen, T., \& Poorundersing, B. (2008). The effectiveness of management accounting systems: evidence from functional managers in a developing country. Managerial Auditing Journal, 23(2), 187-219. https://doi.org/10.1108/02686900810839866

Sprinkle, G. B. (2000). The effect of incentive contracts on learning and performance. The Accounting Review, 75(3), 299-326. https://doi.org/10.2308/accr.2000.75.3.299

Stone, M. (1974). Cross-validatory choice and assessment of statistical predictions. Journal of the Royal Statistical Society: Series B (Methodological), 36(2), 111-133. https://doi.org/10.1111/j.2517-6161.1974.tb00994.x

Tillema, S. (2005). Towards an integrated contingency framework for MAS sophistication: Case studies on the scope of accounting instruments in Dutch power and gas companies. Management Accounting Research, 16(1), 101-129. https://doi.org/10.1016/j.mar.2004.12.001

Vroom, V. H. (1964). Work and motivation. New Jersey: Wiley.

Waterhouse, J. H., \& Tiessen, P. (1978). A contingency framework for management accounting systems research. Accounting, organizations and society, 3(1), 65-76. https://doi.org/10.1016/0361-3682(78)90007-7

Zhao, X., Lynch Jr, J. G., \& Chen, Q. (2010). Reconsidering Baron and Kenny: Myths and truths about mediation analysis. Journal of consumer research, 37(2), 197-206. https://doi.org/10.1086/651257 


\section{Correspondence}

Quang-Huy Ngo

Industrial Management Faculty, Cantho University of

Technology

256 Nguyen Van Cu street, Ninh Kieu district, Cantho City, 920000, Vietnam

Email: nqhuy@ctuet.edu.vn 